\title{
Estimation of Annual Effective Dose Due to Ingestion of Natural Radionuclides in Cattle in Tin Mining Area of Jos Plateau, Nigeria
}

\author{
Janet Ayobami Ademola \\ Department of Physics, University of Ibadan, Ibadan, Nigeria \\ Email: jaaademola@yahoo.com, janet.ademola@mail.ui.edu.ng
}

Received 22 November 2013; revised 22 December 2013; accepted 30 December 2013

Copyright (C) 2014 by author and Scientific Research Publishing Inc.

This work is licensed under the Creative Commons Attribution International License (CC BY).

http://creativecommons.org/licenses/by/4.0/

(c) (i) Open Access

\begin{abstract}
Contamination of land could occur during the extraction and handling of materials containing high levels of naturally occurring radionuclide materials. These radionuclides find their ways into the food chain. The activity concentrations of natural radionuclides ${ }^{40} \mathrm{~K},{ }^{226} \mathrm{Ra}$, and ${ }^{232} \mathrm{Th}$ in heart, liver, kidney, lungs, spleen and beef of cattle slaughtered and consumed in a tin mining area of Jos Plateau, Nigeria were determined by gamma ray spectroscopy method. The activity concentration of ${ }^{40} \mathrm{~K}$ is the highest in all the samples. The annual effective dose to man through the ingestion of the radionuclides in the organs was estimated. The mean annual effective doses calculated are $35.35 \pm$ 13.84, $57.89 \pm 38.27$ and $46.93 \pm 10.28 \mu \mathrm{Sv} \cdot \mathrm{y}^{-1}$ for heart, liver and kidney, respectively. Those of lungs, spleen and meat are $28.44 \pm 15.70,48.34 \pm 28.85$ and $41.24 \pm 3.56 \mu S v \cdot y^{-1}$, respectively. These are of the order of two magnitudes higher than those obtained for food in Abeokuta, Nigeria.
\end{abstract}

\section{Keywords}

Natural Radionuclides; Tin Mining; Contamination; Cattle; Ingestion; Effective Dose

\section{Introduction}

Water resources, agricultural areas, forest and the atmosphere are major biological systems determining the intake of radioactivity by man. Diet is the main source of radioactive elements, and thus of internal radiation dose [1]. A major source of energy for metabolic activities in living organisms is food. Ingestion of radionuclides through food intake accounts for substantial part of average radiation dose to various organs of the body and also represents one of the important pathways for long term health consideration. Radionuclides in soil may enter the food chain through direct deposition on leaves or through translocation to parts of plants that are edible to 
humans and animals [2].

Radioactivity contaminated land can arise as a result of industrial processes, including past waste disposal or accident. Radionuclide could be present on land as a result of a number of past land uses. Contamination of land could occur during the extraction and handling of materials containing high levels of naturally occurring radionuclide materials (NORM) [3]. The intake or ingestion of radionuclide contaminated feed, e.g. grass by animals can concentrate radioactivity in tissues [4]. The uptake of radionuclides by animals is dependent on the animal species, mass, age, and growth rate of animal and the digestibility of the feed. Ingestion of soil during grazing can be an important contributor to intake of activity, particularly for radionuclides that are not taken up readily by grass [5]. Hence, contamination of meat is mainly the result of animal grazing, but contaminated drinking water might also be an important pathway [6]. People can therefore be exposed internally to radionuclides through eating the products of animals which have themselves eat contaminated substances.

The Jos area of Nigeria has been identified as a high background radiation [7] [8]. The waste products (tailing) from the mining of tin ore to obtain tin and columbite are discarded and dumped around the mining sites. Activity concentrations of natural radionuclides in tailings, soil and food in the Jos area had been reported [7]-[11]. The tailings have been found to contain high activity concentrations of ${ }^{238} U$ and ${ }^{232} T$ Th [7] [12]. This could result in internal exposure of the populace through leached activity which may be directly ingested through drinking water or may indirectly enter the food chain by uptake through vegetation, fish, milk and meat. The objective of this work is to investigate the natural radioactivity levels $\left({ }^{226} \mathrm{Ra},{ }^{40} \mathrm{~K}\right.$ and $\left.{ }^{232} \mathrm{Th}\right)$ in different organs of cattle grazed and slaughtered in the area for consumption and also evaluate the population radiation ingestion dose.

\section{Material and Methods}

\subsection{Sample Collection and Preparation}

Different organs of cattle, commonly eaten by the Nigerian populace were collected from an abattoir close to the tin mining area. The cattle slaughtered at the abattoir graze on grass and eat other feed made from combination of grains grown in the area. The organs include heart, liver, kidney, lungs, spleen and beef. All the organs were collected from the same cattle at a cost. The whole organs for each cattle were collected and labeled to avoid mix up. Because of the cost only five cattle were sampled. The samples were frozen before the period of analysis. The organs were oven dried at a temperature of $100^{\circ} \mathrm{C}$ until a constant weight was attained. The dried samples were crushed and grinded. They were weighed and packed in sample containers, sealed and kept for more than four weeks in order to for Ra and Th and their short-lived progenies to attain secular radioactive equilibrium.

\subsection{Radioactivity Measurement}

\subsubsection{Determination of Natural Radionuclides}

The radionuclide contents were determined using a lead-shielded $76 \mathrm{~mm} \times 76 \mathrm{~mm} \mathrm{NaI(Tl)}$ detector crystal (Model No. 802 series, Canberra Inc.) coupled to a Canberra Series 10 plus Multichannel Analyzer (MCA) (Model No. 1104) through a preamplifier. The detector has a resolution of about $8 \%$ at $0.662 \mathrm{MeV}$ of ${ }^{137} \mathrm{Cs}$. This is capable of distinguishing the gamma ray energies considered during these measurements. The uranium-238 and thorium-232 activities were determined indirectly through the activities of their daughter products. The choice of the reference nuclides for their activity determination was made based on the fact that $\mathrm{NaI}(\mathrm{Tl})$ detector has a poor resolution, hence, the peaks of interest to be considered would be sufficiently discriminated and intense. Based on this consideration, therefore, the ${ }^{226} \mathrm{Ra}$ content of the samples was determined from the intensity of the $1760 \mathrm{keV}$ gamma-ray peak from ${ }^{214} \mathrm{Bi}$, the ${ }^{232} \mathrm{Th}$ content from the $2615 \mathrm{keV}$ gamma-ray peak from ${ }^{208} \mathrm{Tl}$ and the ${ }^{40} \mathrm{~K}$ content from $1460 \mathrm{keV}$ gamma-ray peak following the decay of ${ }^{40} \mathrm{~K}$. These peaks are clean, reasonably strong with very low continuum. The energy calibration of the counting system was done as described in Ademola and Olatunji (2013), [13]. The sample container was placed on the detector and each sample was counted for 10 hours.

\subsubsection{Determination of Activity Concentrations of ${ }^{226} \mathrm{Ra},{ }^{232} \mathrm{Th}$ and ${ }^{40} \mathrm{~K}$}

The activity concentrations of the radionuclides were calculated by first determining the detection efficiency $E_{p}$ of the system. The detection efficiency at the constant geometry of counting is defined as [14] [15]; 


$$
E_{p}=\frac{A}{t C Y m}
$$

where $A$ is the net area under the photopeak, $C\left(\mathrm{~Bq} \cdot \mathrm{kg}^{-1}\right)$ is the activity concentration of a reference sample of mass $m(\mathrm{~kg})$ counted for a time $t(\mathrm{~s})$ and $Y$ is the gamma radiation yield. The efficiency was determined using a reference standard source of known activity concentrations, prepared from International Atomic Energy Agency (IAEA), Vienna, Austria and traceable to source Ref No. IAEA-312. The activity concentrations of each radionuclide in the samples were obtained by relating the detection efficiency to the net area under each photopeak.

\section{Results and Discussion}

The activity concentrations of the three radionuclides in the different organs followed no pattern. There are variations in the activity concentrations of ${ }^{40} \mathrm{~K},{ }^{226} \mathrm{Ra}$ and ${ }^{232} \mathrm{Th}$ in the organs from one sample to the other. On the average the activity concentration of ${ }^{40} \mathrm{~K}$ is higher in all the organs. The highest ${ }^{40} \mathrm{~K}$, ${ }^{226} \mathrm{Ra}$ and ${ }^{232} \mathrm{Th}$ contents were found in the liver of sample 2, heart of sample 5 and liver of sample 5, respectively. Figures 1, 2 and 3 show the distribution of ${ }^{40} \mathrm{~K},{ }^{226} \mathrm{Ra}$ and ${ }^{232} \mathrm{Th}$, respectively in the different organs.

Radiation dose received due to the intake of food is calculated from the amount of radionuclide deposited on foodstuff, the activity concentration of particular radionuclide in food per unit deposition, the consumption rate of the food products and the dose per unit activity ingested [16]. Annual effective ingestion dose for an adult member of the public due to the intake of radionuclide through ingestion of food can be calculated based on the metabolic models developed by the International Commission of Radiological Protection [17];

$$
H_{T, r}=\sum\left(U^{i} \times C_{r}^{i}\right) \times g_{T, r}
$$

where, $i$ denotes a food group, the coefficients $U_{i}$ and $C_{r}^{i}$ denote the consumption rate $\left(\mathrm{kg} \cdot \mathrm{y}^{-1}\right)$ and activity concentration of the radionuclide $r$ of interest $\left(\mathrm{Bq} \cdot \mathrm{kg}^{-1}\right)$, respectively, and $g_{T, r}$ is the dose conversion coefficient for ingestion of radionuclide $r\left(\mathrm{~Sv} \cdot \mathrm{Bq}^{-1}\right)$ in tissue $T$. For adult members of the public, the recommended dose conversion coefficient $g_{T, r}$ for ${ }^{40} \mathrm{~K},{ }^{226} \mathrm{Ra}$, and ${ }^{232} \mathrm{Th}$, are $6.2 \times 10^{-9}, 2.8 \times 10^{-7}$ and $2.2 \times 10^{-7} \mathrm{~Sv} \cdot \mathrm{Bq}^{-1}$, respectively [18]. Presently, no site specific consumption data exist in the study area and as a result the average per capita of beef consumption between 1961 and $2007 \mathrm{for}$ Nigeria which is $0.98 \mathrm{~kg} \cdot \mathrm{y}^{-1}$ was used [19]. This value was adopted for the other organs since there is no such data for them. Equation (2) was used to calculate the effective dose due to the intake of beef and other organs.

The results of the effective dose due to intake are presented in column 5 of Tables 1 to 5 . The effective dose

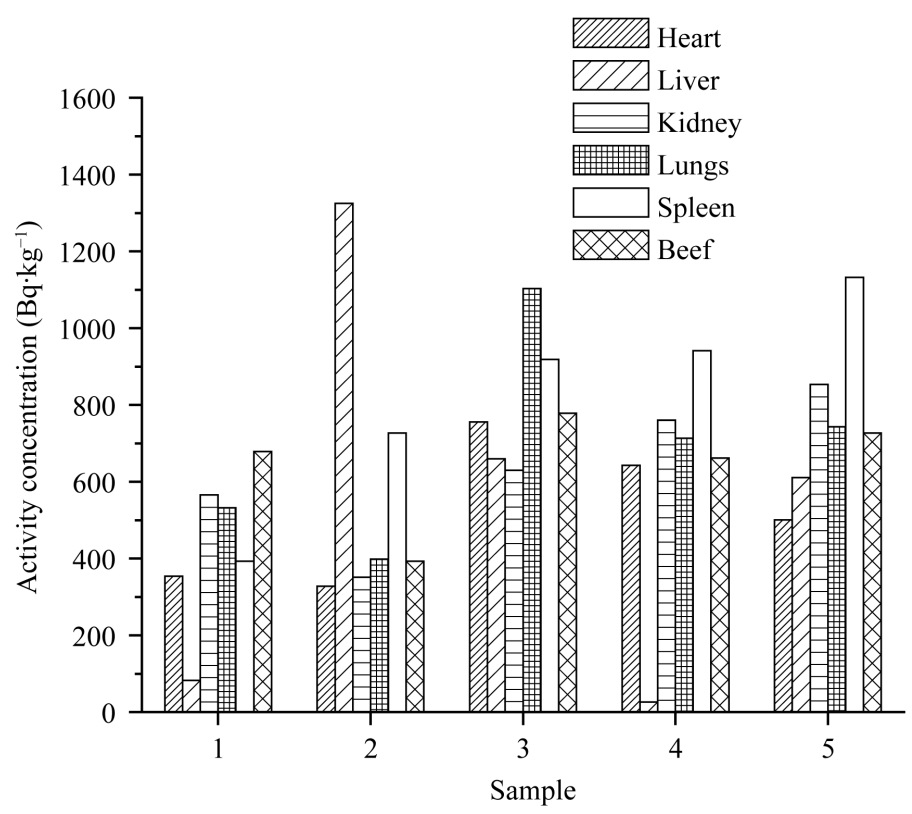

Figure 1. Activity concentration of ${ }^{40} \mathrm{~K}$ in different organs of five cattle. 


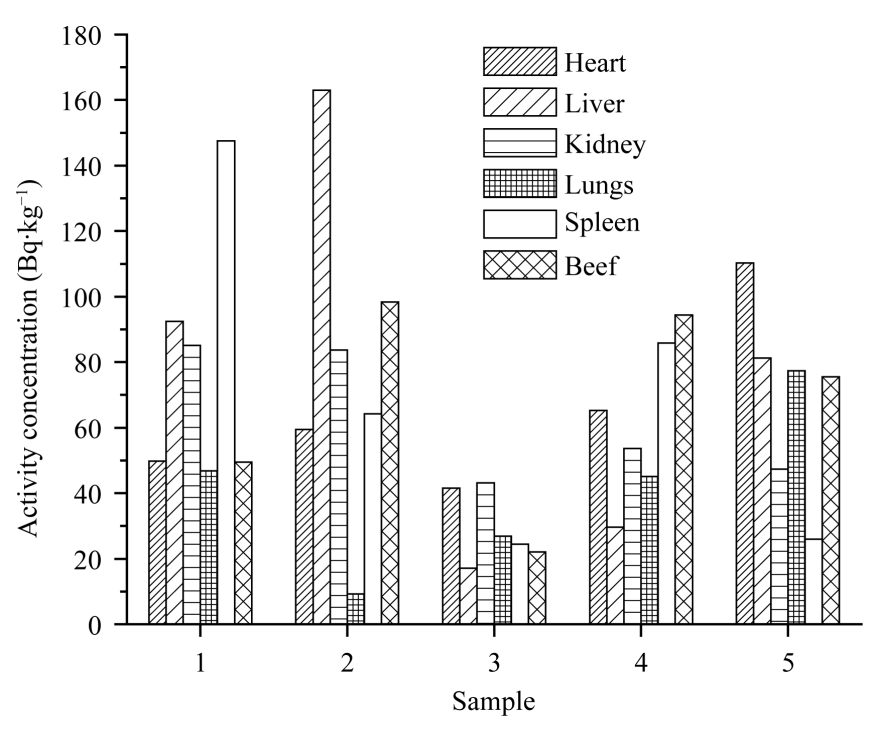

Figure 2. Activity concentration of ${ }^{226} \mathrm{Ra}$ in different organs of five cattle.

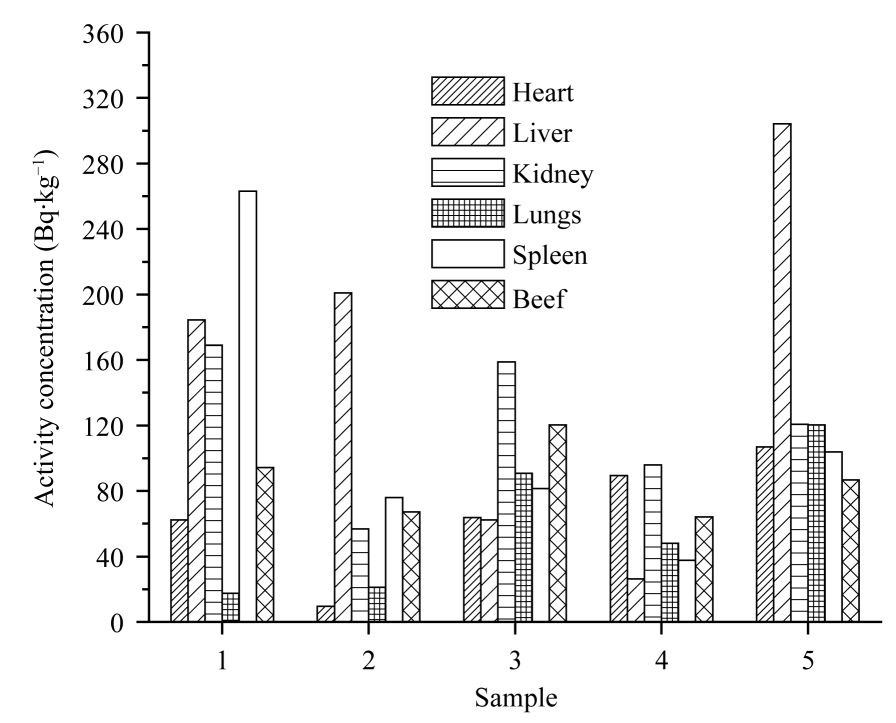

Figure 3. Activity concentration of ${ }^{232}$ Th in different organs of five cattle.

Table 1. Activity concentrations of natural radionuclides and effective dose in different organs of sample 1.

\begin{tabular}{|c|c|c|c|c|}
\hline Organ & ${ }^{40} \mathrm{~K}\left(\mathrm{~Bq} \cdot \mathrm{kg}^{-1}\right)$ & ${ }^{226} \mathrm{Ra}\left(\mathrm{Bq} \cdot \mathrm{kg}^{-1}\right)$ & ${ }^{232} \mathrm{Th}\left(\mathrm{Bq} \cdot \mathrm{kg}^{-1}\right)$ & Effective dose $\left(\mu \mathrm{Sv} \cdot \mathrm{y}^{-1}\right)$ \\
\hline Heart & 354.14 & 49.74 & 62.35 & 29.24 \\
\hline Liver & 81.94 & 92.48 & 184.46 & 65.64 \\
\hline Kidney & 565.8 & 85.15 & 169 & 63.24 \\
\hline Lungs & 532.21 & 46.84 & 17.41 & 19.84 \\
\hline Spleen & 392.38 & 147.55 & 263.13 & 99.6 \\
\hline Beef & 678.67 & 49.49 & 94.29 & 38.03 \\
\hline
\end{tabular}


Table 2. Activity concentrations of natural radionuclides and effective dose in different organs of sample 2.

\begin{tabular}{ccccc}
\hline Organ & ${ }^{40} \mathrm{~K}\left(\mathrm{~Bq} \cdot \mathrm{kg}^{-1}\right)$ & ${ }^{226} \mathrm{Ra}\left(\mathrm{Bq} \cdot \mathrm{kg}^{-1}\right)$ & ${ }^{232} \mathrm{Th}\left(\mathrm{Bq} \cdot \mathrm{kg}^{-1}\right)$ & Effective dose $\left(\mu \mathrm{Sv} \cdot \mathrm{y}^{-1}\right)$ \\
\hline Heart & 327.89 & 59.45 & 9.58 & 20.37 \\
Liver & 1324.48 & 163.03 & 200.92 & 96.1 \\
Kidney & 351.44 & 83.65 & 56.71 & 37.32 \\
Lungs & 398.44 & 9.22 & 21.27 & 9.54 \\
Spleen & 726.86 & 64.28 & 75.93 & 38.43 \\
Beef & 393.12 & 98.39 & 67.17 & 43.87 \\
\hline
\end{tabular}

Table 3. Activity concentrations of natural radionuclides and effective dose in different organs of sample 3.

\begin{tabular}{ccccc}
\hline Organ & ${ }^{40} \mathrm{~K}\left(\mathrm{~Bq} \cdot \mathrm{kg}^{-1}\right)$ & ${ }^{226} \mathrm{Ra}\left(\mathrm{Bq} \cdot \mathrm{kg}^{-1}\right)$ & ${ }^{232} \mathrm{Th}\left(\mathrm{Bq} \cdot \mathrm{kg}^{-1}\right)$ & ${\text { Effective dose }\left(\mu \mathrm{Sv} \cdot \mathrm{y}^{-1}\right)}^{\text {Heart }}$ \\
755.96 & 41.49 & 63.81 & 29.74 \\
Liver & 660.08 & 17.13 & 62.4 & 22.16 \\
Kidney & 630.2 & 43.14 & 158.75 & 49.89 \\
Lungs & 1103.14 & 26.88 & 90.87 & 33.67 \\
Spleen & 918.12 & 24.42 & 81.35 & 29.89 \\
Beef & 778.13 & 22.06 & 120.33 & 36.72 \\
\hline
\end{tabular}

Table 4. Activity concentrations of natural radionuclides and effective dose in different organs of sample 4.

\begin{tabular}{ccccc}
\hline Organ & ${ }^{40} \mathrm{~K}\left(\mathrm{~Bq} \cdot \mathrm{kg}^{-1}\right)$ & ${ }^{226} \mathrm{Ra}\left(\mathrm{Bq} \cdot \mathrm{kg}^{-1}\right)$ & ${ }^{232} \mathrm{Th}\left(\mathrm{Bq} \cdot \mathrm{kg}^{-1}\right)$ & ${\text { Effective dose }\left(\mu \mathrm{Sv} \cdot \mathrm{y}^{-1}\right)}^{\text {Heart }}$ \\
642.43 & 65.24 & 89.3 & 41.06 \\
Liver & 25.86 & 29.65 & 26.36 & 13.98 \\
Kidney & 760.39 & 53.63 & 95.99 & 39.96 \\
Lungs & 713.21 & 45.12 & 48.04 & 27.07 \\
Spleen & 941.04 & 85.81 & 37.64 & 37.38 \\
Beef & 661.23 & 94.36 & 64.06 & 43.72 \\
\hline
\end{tabular}

Table 5. Activity concentrations of natural radionuclides and effective dose in different organs of sample 5.

\begin{tabular}{ccccc}
\hline Organ & ${ }^{40} \mathrm{~K}\left(\mathrm{~Bq} \cdot \mathrm{kg}^{-1}\right)$ & ${ }^{226} \mathrm{Ra}\left(\mathrm{Bq} \cdot \mathrm{kg}^{-1}\right)$ & ${ }^{232} \mathrm{Th}\left(\mathrm{Bq} \cdot \mathrm{kg}^{-1}\right)$ & ${\text { Effective dose }\left(\mu \mathrm{Sv} \cdot \mathrm{y}^{-1}\right)}^{-10.27}$ \\
Heart & 500.58 & 110.27 & 106.83 & 56.33 \\
Liver & 610.43 & 81.21 & 304.18 & 91.57 \\
Kidney & 853.69 & 47.37 & 120.74 & 44.22 \\
Lungs & 742.79 & 77.39 & 120.3 & 51.69 \\
Spleen & 1132.34 & 25.92 & 103.85 & 36.38 \\
Beef & 726.55 & 75.59 & 86.74 & 43.86 \\
\hline
\end{tabular}

due to the ingestion of ${ }^{40} \mathrm{~K}{ }^{226} \mathrm{Ra}$ and ${ }^{232} \mathrm{Th}$ through the consumption of the heart ranged between 20.37 and $56.33 \mu \mathrm{Sv} \cdot \mathrm{y}^{-1}$ with a mean value of $35.35 \pm 13.84 \mu \mathrm{Sv} \cdot \mathrm{y}^{-1}$. That of liver varied from 13.89 to $96.10 \mu \mathrm{Sv} \cdot \mathrm{y}^{-1} \mathrm{with}$ a mean value of $57.89 \pm 38.27 \mu \mathrm{Sv} \cdot \mathrm{y}^{-1}$. Kidney, varied from 37.32 to $63.24 \mu \mathrm{Sv} \cdot \mathrm{y}^{-1}$ with a mean value of 46.93 $\pm 10.28 \mu \mathrm{Sv} \cdot \mathrm{y}^{-1}$. For lungs and spleen, the values ranged from 9.94 to $51.69 \mu \mathrm{Sv} \cdot \mathrm{y}^{-1}$ and 29.89 to $99.60 \mu \mathrm{Sv} \cdot \mathrm{y}^{-1}$ with mean values of $28.44 \pm 15.70 \mu \mathrm{Sv}^{\cdot} \mathrm{y}^{-1}$ and $48.34 \pm 28.85 \mu \mathrm{Sv}^{\cdot} \mathrm{y}^{-1}$. The beef varied between 36.72 to 43.87 $\mu \mathrm{Sv} \cdot \mathrm{y}^{-1}$ with a mean value of $41.24 \pm 3.56 \mu \mathrm{Sv} \cdot \mathrm{y}^{-1}$. The errors quoted are the standard deviations from the mean values which depict the variation of the effective dose within each organ. The standard deviation of the mean of the beef samples shows little variation in the effective dose. Figure 4 shows a chart of the effective dose due to the ingestion of the radionuclide in the different organs. The results obtained in this study are of the order of 2 magnitudes higher than those obtained by Jibiri and Abiodun (2013), for food diet in Abeokuta, Southwestern 


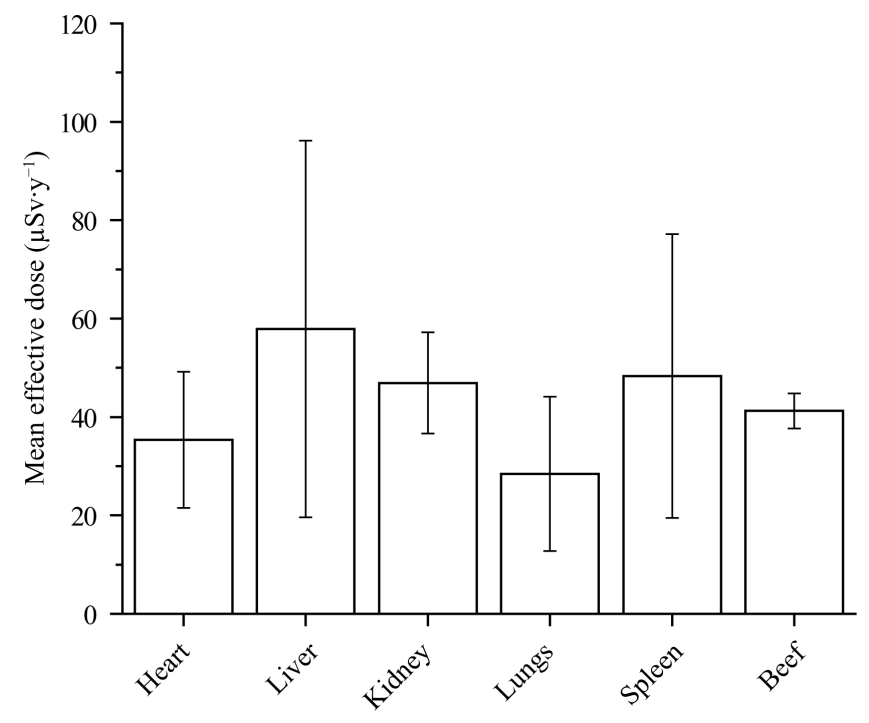

Figure 4. Mean annual effective dose due to the ingestion of ${ }^{40} \mathrm{~K}$, ${ }^{226} \mathrm{Ra}$ and ${ }^{232} \mathrm{Th}$ in different organs of cattle.

Nigeria [16].

\section{Conclusion}

The activity concentrations of natural radionuclides, ${ }^{40} \mathrm{~K},{ }^{226} \mathrm{Ra}$ and ${ }^{232} \mathrm{Th}$ in different organs of cattle slaughtered and consumed in a high background radiation area had been measured using gamma ray spectroscopy method. On the average ${ }^{40} \mathrm{~K}$ was found to be the highest in all the organs. The annual effective dose due the ingestion of the radionuclides in the organs was estimated. The mean annual effective varied from $28.44 \pm 15.70 \mu \mathrm{Sv} \cdot \mathrm{y}^{-1}$ (lungs) to $57.89 \pm 38.27 \mu \mathrm{Sv} \cdot \mathrm{y}^{-1}$ (liver).

\section{References}

[1] Gaso, M.I., Segovia, N., Cervantes, M.L., Herrera, T. and Perez-Silva, E. (2000) Internal Radiation Dose from 137Cs Due to the Consumption of Mushrooms from the Mexican Temperate Mixed Forest. Radiation Protection Dosimetry, 87, 213-216. http://dx.doi.org/10.1093/oxfordjournals.rpd.a033000

[2] Avadhani, D.N., Mahesh, H.M, Karunakara, N., Narayana, K., Somashekarappa, H.M. and Siddappa, K. (2001) Dietary Intake of 210Po and 210Pb in the Environment of Goa of South-West Coast of India. Health Physics, 81, 438-445. http://dx.doi.org/10.1097/00004032-200110000-00008

[3] Oatway, W.B. and Mobbs, S.F. (2003) Methodology for Estimating the Dose to Members of the Public from the Future Use of Land Previously Contaminated with Radioactivity. National Radiological Protection Board, NRPB-W36, Chilton March 2003.

[4] Center for Food Safety-Nuclear Event and Food Safety (2013) The Government of the Hong Kong Special Administrative Region. http://www.cfs.gov.hk/english/programme/programme rafs/programme rafs fc 0130 Q\&A 2.html

[5] Ewers, L.W., Ham, G.J. and Wilkins, B.T. (2003) Review of the Transfer of Naturally Occurring Radionuclides to Terrestrial Plants and Domestic Animals. National Radiological Protection Board, NRPB-W49, Chilton October 2003.

[6] International Atomic Energy Agency (1989) Measurement of Radionuclides in Food and the Environment. A Guidebook, Technical Reports Series No. 295, IAEA, Vienna.

[7] Oresegun, M.O. and Babalola, I.A. (1993) The Environmental Gamma Radiation Level of Jos, Nigeria. Nigerian Journal of Science, 27, 263-268.

[8] Ademola, J.A. (2008) Exposure to High Background Radiation Level at Tin Mining Area of Jos Plateau, Nigeria. Journal of Radiological Protection, 28, 93-99. http://dx.doi.org/10.1088/0952-4746/28/1/006

[9] Babalola, I.A. (1984) Radiation Measurement and Assay of Tailing from High Natural Radioactivity in Plateau State. Nigerian Journal of Science, 18, 98-101. 
[10] Jibiri, N.N. (2001) Assessment of Health Risk Associated with Terrestrial Gamma Radiation Dose Rate Levels in Nigeria. Environment International, 27, 21-26. http://dx.doi.org/10.1016/S0160-4120(01)00039-3

[11] Jibiri, N.N., Farai, I.P. and Alausa, S.K. (2007) Estimation of Annual Effective Dose Due to Natural Radioactive Elements in Ingestion of Foodstuffs in Tin Mining Area of Jos-Plateau, Nigeria. Journal of Environmental Radioactivity, 94, 31-40. http://dx.doi.org/10.1016/j.jenvrad.2006.12.011

[12] Oresegun, M.O. and Babalola, I.A. (1990) Occupational Radiation Exposure Associated with Miling of Th-U Rich Sn in Nigeria. Health Physics, 58, 213-215.

[13] Ademola, J.A. and Olatunji, M.A. (2013) Evaluation of NORM and Dose Assessment in an Aluminium Industry in Nigeria. World Journal of Nuclear Science and Technology, 3, 150-154. http://dx.doi.org/10.4236/wjnst.2013.34025

[14] Farai, I.P. and Ademola, J.A. (2005) Radium Equivalent Activity Concentrations in Concrete Building Blocks in Eight Cities in Southwestern Nigeria. Journal of Environmental Radioactivity, 79, 119-125. http://dx.doi.org/10.1016/j.jenvrad.2004.05.016

[15] Bruzzi, L., Baroni, M., Mazzott, G., Mele, R. and Righi, S. (2000) Radioactivity in Raw Materials and End Products in the Italian Ceramic Industry. Journal of Environmental Radioactivity, 47, 171-181. http://dx.doi.org/10.1016/S0265-931X(99)00026-0

[16] Jibiri, N.N. and Abiodun, T.H. (2012) Effects of Food Diet Preparation Techniques on Radionuclide Intake and Its Implications for Individual Ingestion Effective Dose in Abeokuta, Southwestern Nigeria. World Journal of Nuclear Science and Technology, 2, 106-113. http://dx.doi.org/10.4236/wjnst.2012.23016

[17] International Commission on Radiological Protection (ICRP) (1996) Age-Dependent Doses to Members of the Public from Intake of Radionuclides: Part 5 Compilations of Ingestion and Inhalation Dose Coefficients (ICRP Publication 72), Pergamon Press, Oxford.

[18] (1996) International Basic Safety Standard for Protection against Ionizing Radiation and for the Safety of Radiation Sources. Safety Series No. 115, International Atomic Energy Agency (IAEA), Vienna.

[19] Ogundari, K. (2012) Demand for Quantity versus Quality in Beef, Chicken and Fish Consumption in Nigeria. Revista de Econimia E Agronegócio, 10, 29-50. 